\title{
A Study on Optical Properties of Zinc Silicate Glass-Ceramics as a Host for Green Phosphor
}

\author{
Siti Aisyah Abdul Wahab ${ }^{1}$, Khamirul Amin Matori ${ }^{1,2, *}$, Mohd Hafiz Mohd Zaid ${ }^{1,2}$, \\ Mohd Mustafa Awang Kechik ${ }^{2}{ }^{(D}$, Sidek Hj Ab Aziz ${ }^{2}$, Rosnita A. Talib ${ }^{3}$, \\ Aisyah Zakiah Khirel Azman ${ }^{1}$, Rahayu Emilia Mohamed Khaidir ${ }^{1}$, \\ Mohammad Zulhasif Ahmad Khiri ${ }^{1}$ and Nuraidayani Effendy ${ }^{2}$ \\ 1 Materials Synthesis and Characterization Laboratory, Institute of Advanced Technology, \\ Universiti Putra Malaysia, UPM Serdang, Selangor 43400, Malaysia; aisyahwahab94@gmail.com (S.A.A.W.); \\ mhmzaid@upm.edu.my (M.H.M.Z.); aisyahzakiah245@gmail.com (A.Z.K.A.); \\ rahayuemilia.upm@gmail.com (R.E.M.K.); mzulhasif@gmail.com (M.Z.A.K.) \\ 2 Department of Physics, Faculty of Science, Universiti Putra Malaysia, UPM Serdang, \\ Selangor 43400, Malaysia; mmak@upm.edu.my (M.M.A.K.); sidek@upm.edu.my (S.H.A.A.); \\ aidayanieffendy@gmail.com (N.E.) \\ 3 Department of Process and Food Engineering, Faculty of Engineering, Universiti Putra Malaysia, \\ UPM Serdang, Selangor 43400, Malaysia; rosnita@upm.edu.my \\ * Correspondence: khamirul@upm.edu.my; Tel.: +6016-267-3321
}

Received: 13 April 2020; Accepted: 6 May 2020; Published: 18 July 2020

\begin{abstract}
For the very first time, a study on the crystallization growth of zinc silicate glass and glass-ceramics was done, in which white rice husk ash (WRHA) was used as the silicon source. In this study, zinc silicate glass was fabricated by using melt-quenching methods based on the composition $(\mathrm{ZnO})_{0.55}(\mathrm{WRHA})_{0.45}$, where zinc oxide $(\mathrm{ZnO})$ and white rice husk ash were used as the raw materials. The control crystallization technique was used in which the sample was sintered at $700-950{ }^{\circ} \mathrm{C}$; then, the physical, structural, and optical properties of the glass and glass-ceramics were investigated by using a densitometer, linear shrinkage, X-ray diffraction (XRD), Fourier transform infrared radiation (FTIR), field-emission scanning electron microscopy (FESEM), and photoluminescence spectroscopy (PL). The density and linear shrinkage increased as the crystallinity increased and the XRD results showed the progression of the crystal formation, in which the sample was still in an amorphous state at $27^{\circ} \mathrm{C}$ and $700{ }^{\circ} \mathrm{C}$; the crystalline phase started at $750{ }^{\circ} \mathrm{C}$. Based on the FTIR spectra, all samples showed sharpened absorption bands as the sintering temperature was increased, and the FESEM image showed the progression of crystal growth, indicating the formation of zinc silicate glass-ceramics. Lastly, the PL spectra emitted three emission peaks, at 529, 570, and $682 \mathrm{~nm}$ for the green, yellow, and red emission, respectively.
\end{abstract}

Keywords: glass; glass-ceramics; sintering; crystallinity; crystal growth; luminescence

\section{Introduction}

Over the past years, in countries that produce rice, like India, China, Bangladesh, Brazil, USA, Cambodia, Vietnam, Myanmar, and the rest of Southeast Asia, a massive amount of agricultural waste was obtained and sometimes had been discarded as waste product [1]. The production of rice in paddies all over the world is approximated to be 600 million tons a year, where $20 \%$ of the crop yield is the husk-to-paddy ratio, and $18 \%$ is the ash-to-husk ration, making the overall ash production 21 million tons per year [2]. However, nowadays, people found a path to use the rice husk (RH) in a more beneficial way, instead of it being a waste product. Several research studies have focused on the properties of rice husk, finding that, among all the countries around the world that produce 
rice, their factories had started to use the rice husk $(\mathrm{RH})$ as an energy source, especially in milling operations and also for household lighting in the countryside areas [3]. This is because rice husk ash has several properties that, depending on the combustion method, makes it beneficial in many ways.

Burning of the RH at higher temperatures produces white rice husk ash (WRHA). In previous studies, it has been found that combusted WRHA contains $95.60 \% \mathrm{SiO}_{2}$ [4]. This finding of a huge amount of silica in the combusted WRHA makes it a precious material, since it can be used as the silica precursor to produce silicate glasses and many other products, such as ceramic tiles. In fact, it had been proven by Bondoli and co-researchers that by using the wasted WRHA as the silica source, an exact same product of industrial glass that has the same glassy characteristic can be produced [2]. Apart from that, silicate glass from WRHA had recently been researched as a potential luminescence material. In previous research, Khaidir and co-researchers conducted research regarding the europium oxide-doped zinc silicate glasses derived from WRHA. From the result obtained, when doping zinc silicate glass with europium oxide, the photoluminescence revealed red emission at $\sim 722 \mathrm{~nm}$ and the emission occurred due to the $4 \mathrm{f}-4 \mathrm{f}$ transition of the europium ions [5]. Besides, another study regarding the luminescence properties of zinc silicate glass doped with cobalt oxide derived from WRHA also had been carried out by Wahab and co-researchers. In 2018, Wahab and co-researchers had found that zinc silicate glass and glass-ceramics from WRHA doped with cobalt oxide emitted a red emission under UV light. The peak was attributed to the d-d transition of the cobalt oxide ions [6]. However, a luminescence study of undoped zinc silicate glass and glass-ceramics derived from WRHA is rare to be found. Hence, for this high composition of silica in the WRHA and its potential as a luminescence material, a comprehensive study regarding the fabrication and characterization of zinc silicate (willemite) will be reported.

Zinc silicate $\left(\mathrm{Zn}_{2} \mathrm{SiO}_{4}\right)$ or willemite is well known among researchers as a supreme and most suitable host matrix for glass phosphor and other optoelectronic materials, since it has a quite huge band gap around $5.5 \mathrm{eV}$, high chemical compound stability, and a great glass transparency [7]. Besides, it also has another special feature-a large excitation binding energy-allowing it to be used as an enhancer for triggering the luminescence inside the neon discharged lamps, fluorescent lamps, black-and-white televisions, colour televisions, oscilloscopes, laser technology, optical communications, optical fibre amplifiers, waveguides, and light emitting diodes (LED) [8-10]. Nowadays, the production of low-cost zinc silicate glass and glass-ceramics is a topic of interest among researchers. In this present work, the fabrication of a novel zinc silicate glass and glass-ceramics fabricated from WRHA by using conventional melt and quenching methods is reported. The best part of this work is the utilization of WRHA as the silicon source instead of using pure silica, which is very expensive. Thus, this will reduce the cost of production of zinc silicate glass and glass-ceramics; it is also very environmentally friendly, economically safe, and has low energy consumption. In this context, the major purpose of this work is to produce, characterize, and study the luminescence of zinc silicate glass and glass-ceramics that had been produced from waste materials (WRHA), as a potential material to be used in optical application.

\section{Materials and Methods}

The RH used was collected from a local rice factory located at Tanjung Karang, Selangor, Malaysia, where the species of the RH is recognized as Oryza sative (Asian rice) [4]. At an earlier state, after being milled, the RH was kept indoor inside the factory to reduce the chances of contamination from the surroundings. The RH was washed numerous times by using pipe water to remove stains and impurities. By using a large basin, the RH was soaked in water and the sands and soils submerged to the bottom of the basin. After that, only the RH that floated on the surface of the water was collected. Then, the washed $\mathrm{RH}$ was dried in an oven at $120^{\circ} \mathrm{C}$ for $8 \mathrm{~h}$. The dried $\mathrm{RH}$ was then burned in the electrical furnace at $1000{ }^{\circ} \mathrm{C}$ for $2 \mathrm{~h}$ at a heating rate $10^{\circ} \mathrm{C} / \mathrm{min}$ to obtain the WRHA. Subsequently, the obtained WRHA was ground by using a mortar and pestle. In order to obtain the fine powder, the WRHA was then sieved into the size of $45 \mu \mathrm{m}$. The obtained WRHA was then mixed with ZnO. 
A zinc silicate glass with a weight composition of $(\mathrm{ZnO})_{0.55}(\mathrm{WRHA})_{0.45}$ was prepared by using the solid state method [2]. In this research, the raw material used was zinc oxide $(\mathrm{ZnO})(99.9 \%$, Sigma Aldrich, Subang Jaya, Malaysia) and WRHA was extracted as mentioned previously. The $\mathrm{ZnO}$ and WRHA were weighed by using an electronic balance for about $\sim 16.5 \mathrm{~g}$ and $\sim 13.5 \mathrm{~g}$, respectively, to give the total amount of $\sim 30 \mathrm{~g}$ of the whole mixture. The mixture was then dry milled by using a milling machine at $80 \mathrm{rpm}$ for one hour to ensure that the composition was well mixed together. Right after the mixture was milled together, it was carefully poured into a cylindrical alumina crucible of $47 \mathrm{~mm}$ in height and with a wall thickness of $2.5 \mathrm{~mm}$, which has the ability to withstand high temperatures of up to $1600^{\circ} \mathrm{C}$; then, the mixture was melted in a closed electrical furnace at $1450{ }^{\circ} \mathrm{C}$ for $3 \mathrm{~h}$. In the meantime, a pail of water with a glass collector at the bottom of the pail was prepared. After the melting process was done, a flowy molten glass was obtained inside the alumina crucible and it was poured into the pail of water. As a result, transparent glass frits were formed. The collected glass frits were left to dry at room temperature and ground by using a plunger, mortar, and pestle to obtain the fine powder, and then sieved at $45 \mu \mathrm{m}$. In order to get the pallet for the purpose of ceramization, a palleting procedure was carried out. The powder was mixed with polyvinyl alcohol (PVA) to bind it together and later was put into the stainless-steel mould that was $13 \mathrm{~mm}$ in diameter and $2 \mathrm{~mm}$ in thickness. Lastly, the powder was pressed by using a uniaxial pressing pallet with an applied load of 3 tons for $10 \mathrm{~min}$. The pallet was then subjected to the sintering process at various sintering temperatures, ranging from 700 to $950{ }^{\circ} \mathrm{C}$, with an increment of $50^{\circ} \mathrm{C}$ for each sample in a $4 \mathrm{~h}$ duration. The zinc silicate glass and glass-ceramics were characterized for their physical, structural and optical properties.

The densities of the zinc silicate glass and glass-ceramics were measured by using an MD-300S densitometer in which Archimedes' principle was applied. The results obtained were compared with true density that was measured by using a micromeritics AccuPyc II 1340 Gas Pycnometer. For bulk density by using Archimedes principle, at the beginning stage, the samples were weighed by using the weighing machine in the air, giving their weight in air $\left(\mathrm{W}_{\mathrm{a}}\right)$. Then, it was followed by the submersion of the sample into liquid, to obtain the weight of the displaced fluid. Then, the density of the sample was calculated by using the following formula:

$$
\rho_{\text {sample }}=\frac{w_{a}}{w_{a}-w_{b}} \times \rho_{\text {distilled water }}
$$

where $\rho_{\text {sample }}$ is the density of the sample, $w_{a}$ is the weight of the sample measured in the air, and $w_{b}$ is the weight of the sample measured in the reference liquid (distilled water was used in this experiment). On the other hand, the true density was determined by using Boyle's law:

$$
\mathrm{P}_{1} \mathrm{~V}_{1}=\mathrm{P}_{2} \mathrm{~V}_{2}
$$

where $P_{1}$ is the pressure $1, V_{1}$ is the volume $1, P_{2}$ is the pressure 2 , and $V_{2}$ is the volume 2 . When the testing was carried out, the calculation of the sample's volume was calculated by the program in the machine by using the rearranged Boyle's law as below:

$$
V_{s}=V_{c}-\frac{V_{E}}{\mathrm{P} 1 \mathrm{P} 2-1}
$$

where $V_{S}$ is the volume of the sample, $V_{c}$ is the volume of the sample's cell, and $V_{E}$ is the volume of the expansion cell. After that, the true density of the sample was calculated by using the formula below:

$$
\rho_{t}=m / V_{s}
$$

where $\rho_{t}$ is the true density and $m$ is the mass of the sample. As for the true density, it measures just the volume of the solid materials and exclude the volume of all open pores. Contrarily, in bulk density (using Archimedes' principle), it includes the volume of all pores both open and close within the sample. Meanwhile, linear shrinkage was determined by calculating the change in the percentage 
of the diameter of the sample by using an electronic vernier calliper. The structural properties of the zinc silicate glasses were examined by X-ray techniques, with an X'pert PRO MPD diffractometer (PANalytical, Philips, Amelo, the Netherlands and Malvern (UK), carried out with Ni-filtered Cu-Ka radiation $=1.5405^{\circ}$ positioned from $20^{\circ}$ to $80^{\circ}$. The molecular vibrations of the precursor glasses were observed by using a Fourier transform infrared spectrometer (FTIR Spectrum 100, Perkin Elmer, Waltham, MA, USA), ranging from 400 to $2000 \mathrm{~cm}^{-1}$. The microstructure of the sample was performed by using field-emission scanning electron microscopy (FESEM), using a FEI NOVA NanoSEM 230, Hillsboro, OR, USA. Lastly, the photoluminescence spectra of the zinc silicate glass were measured by using a spectrometer, in this case the Perkin Elmer LS 55 Fluorescence Spectrometer instrument.

\section{Results}

\subsection{Density and Linear Shrinkage}

The Archimedes density (density that is measured by using Archimedes' principle) accompanied by the linear shrinkage as a function of the sintering temperature was plotted as portrayed in Figure 1 . Then, the Archimedes density was also compared with the true density as in Table 1. From Figure 1, the densities of the samples were increased from 2.9118 to $3.4138 \mathrm{~g} / \mathrm{cm}^{3}$ as the sintering temperature increased. Meanwhile, the true density also increased as the sintering temperature increased from 2.3734 to $3.4472 \mathrm{~g} / \mathrm{cm}^{3}$. Besides, from Figure 1, it can be observed that the zinc silicate glass and glass-ceramics shrinkage increased from $0 \%$ to $7.5 \%$.

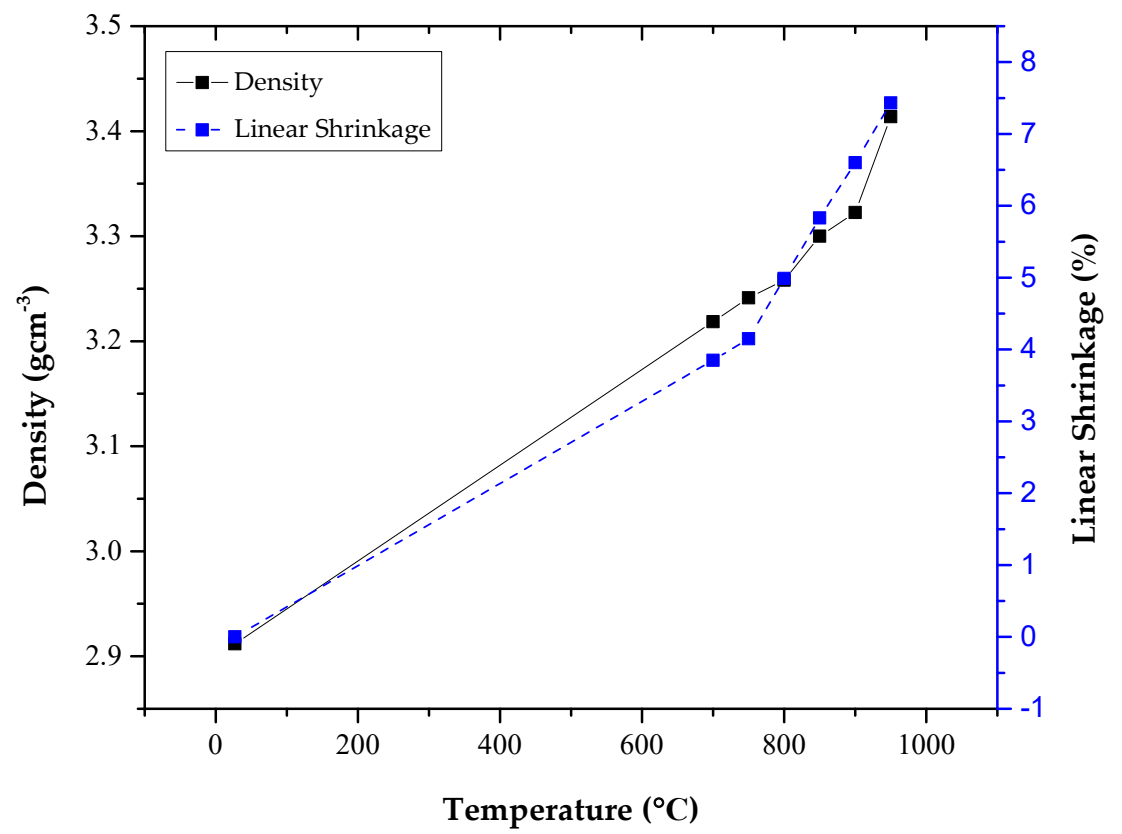

Figure 1. Density accompanied by the linear shrinkage of the zinc silicate glass and glass-ceramics that were heat treated at various sintering temperatures.

Table 1. Comparison of the values measured from the Archimedes density and true density.

\begin{tabular}{cccccccc}
\hline Sintering Temperature $\left({ }^{\circ} \mathbf{C}\right)$ & $\mathbf{2 7}$ & $\mathbf{7 0 0}$ & $\mathbf{7 5 0}$ & $\mathbf{8 0 0}$ & $\mathbf{8 5 0}$ & $\mathbf{9 0 0}$ & $\mathbf{9 5 0}$ \\
\hline Archimedes density $\left(\mathrm{g} / \mathrm{cm}^{3}\right)$ & 2.9118 & 3.2186 & 3.2413 & 3.2581 & 3.3001 & 3.3225 & 3.4138 \\
True density $\left(\mathrm{g} / \mathrm{cm}^{3}\right)$ & 2.3745 & 2.5482 & 3.4036 & 3.4164 & 3.4240 & 3.4329 & 3.4472 \\
\hline
\end{tabular}

\subsection{X-ray Diffraction}

The XRD patterns of the zinc silicate glass and glass-ceramic heat treated at different temperature ranging from 700 to $950{ }^{\circ} \mathrm{C}$ for $4 \mathrm{~h}$ are discretely presented in Figure 2. At room temperature and 
$700{ }^{\circ} \mathrm{C}$, the XRD patterns showed a broad amorphous characteristic, indicating that the samples are still glass in nature. However, as the sintering temperature increased to $750{ }^{\circ} \mathrm{C}$, a sharp peak started to appear and the $\beta$ phase of the zinc silicate $\left(\beta-\mathrm{Zn}_{2} \mathrm{SiO}_{4}\right)$ with a JCPDS no. of 14-0653 was detected to be formed. $\beta-\mathrm{Zn}_{2} \mathrm{SiO}_{4}$ is known to be the thermodynamically metastable phases of zinc silicate (willemite) that has an orthorhombic crystal system (from a recent study) [11,12]. In Figure 2, thirteen major diffraction peaks of $\beta-\mathrm{Zn}_{2} \mathrm{SiO}_{4}$ at $2 \theta=22.04^{\circ}, 25.23^{\circ}, 27.10^{\circ}, 31.20^{\circ}, 36.23^{\circ}, 37.84^{\circ}, 42.44^{\circ}, 44.90^{\circ}, 47.84^{\circ}$, $56.19^{\circ}, 61.22^{\circ}$, and $65.38^{\circ}$, corresponding to planes (210), (020), (12-1), (112), (221), (022), (231), (420), (40-2), (322), (511), (332), and (33-3), respectively, were detected and indexed as shown in Figure 2. This $\beta-\mathrm{Zn}_{2} \mathrm{SiO}_{4}$ continued to exist until the sintering temperature reached $850{ }^{\circ} \mathrm{C}$.

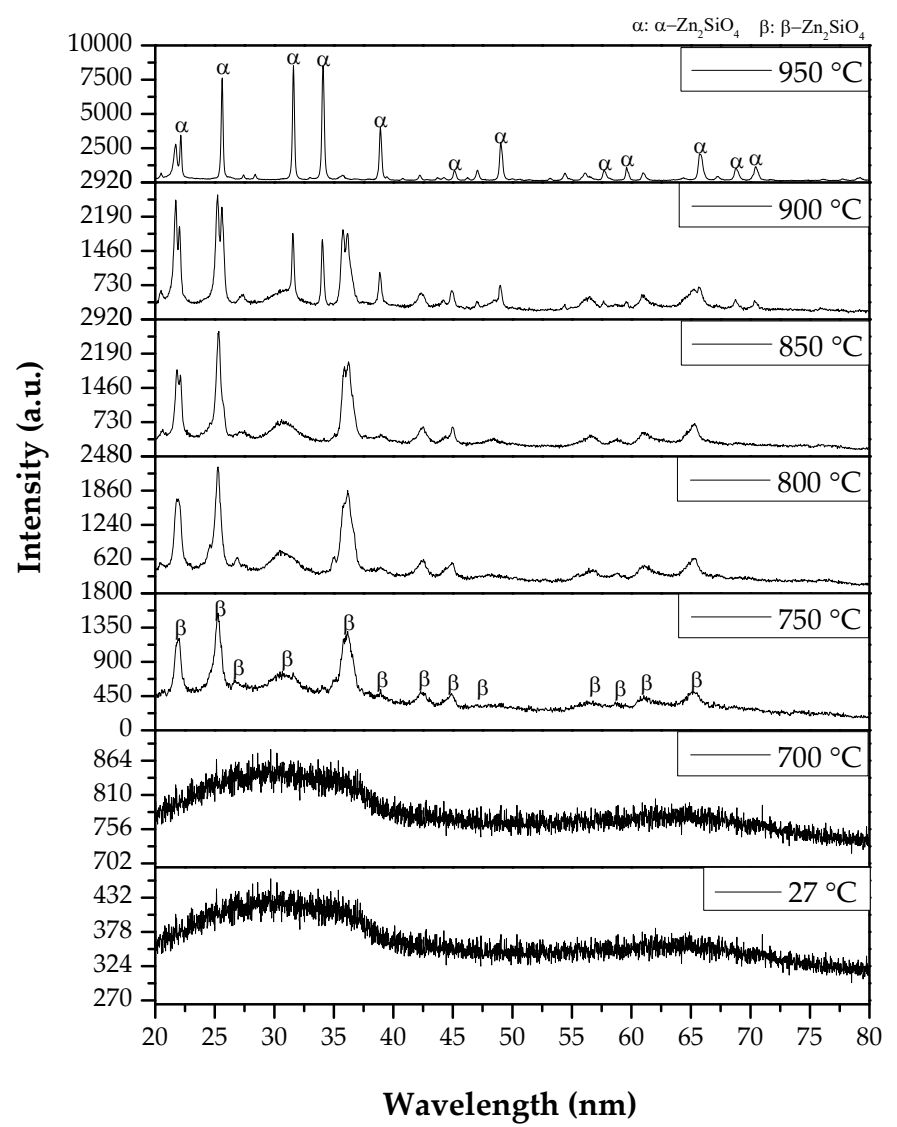

Figure 2. X-ray diffraction patterns of the zinc silicate glass and glass-ceramics that were heat treated at various sintering temperatures.

Meanwhile, when the sintering temperature of the sample increased to $900{ }^{\circ} \mathrm{C}$, the $\beta-\mathrm{Zn}_{2} \mathrm{SiO}_{4}$ phase transformed into $\alpha-\mathrm{Zn}_{2} \mathrm{SiO}_{4}$ phases (JCPDS no. 37-1485). The $\alpha-\mathrm{Zn}_{2} \mathrm{SiO}_{4}$ phase is a nesosilicate, or previously known as an orthosilicate, consisting of isolated $\mathrm{SiO}_{4}{ }^{4-}$ tetrahedrons and $\mathrm{ZnO}_{4}{ }^{6-}[13,14]$. It is the most common practical crystalline phase of zinc silicate. At $900{ }^{\circ} \mathrm{C}$, there were still a few of the $\beta-\mathrm{Zn}_{2} \mathrm{SiO}_{4}$ phases being traced. However, as the temperature increased to $950^{\circ} \mathrm{C}$, only a single phase of $\alpha-\mathrm{Zn}_{2} \mathrm{SiO}_{4}$ was seen. There were twelve major diffraction peaks found, as indicated in Figure 1, where the diffraction peaks positioned at $2 \theta=22.12^{\circ}, 25.59^{\circ}, 31.53^{\circ}, 34.07^{\circ}, 38.88^{\circ}, 45.10^{\circ}, 46.84^{\circ}$, $49.01^{\circ}, 57.85^{\circ}, 59.77^{\circ}, 65.73^{\circ}, 68.77^{\circ}$, and $70.45^{\circ}$ corresponded to planes (330), (220), (113), (410), (223), (060), (431), (333), (8-70), (006), (8-73), (636), and (416), respectively. Therefore, it can be concluded that, as the sintering temperature increases, the glass gradually changes into glass-ceramics, where the crystallization of the $\beta-\mathrm{Zn}_{2} \mathrm{SiO}_{4}$ occurred first at the lower temperature, and then gradually was converted into the thermodynamically stable state of $\alpha-\mathrm{Zn}_{2} \mathrm{SiO}_{4}$. 


\subsection{Field-Emission Scanning Electron Microscopy (FESEM)}

The FESEM micrographs of the zinc silicate glass and glass-ceramics sintered at $700-950{ }^{\circ} \mathrm{C}$ with 10,000x magnification are presented in Figure 3. There was no grain growth observed at $27^{\circ} \mathrm{C}$ and $700{ }^{\circ} \mathrm{C}$. Then, upon further sintering, the sample started to aggregate, showing the growth effect of the sintering temperature.

(a)

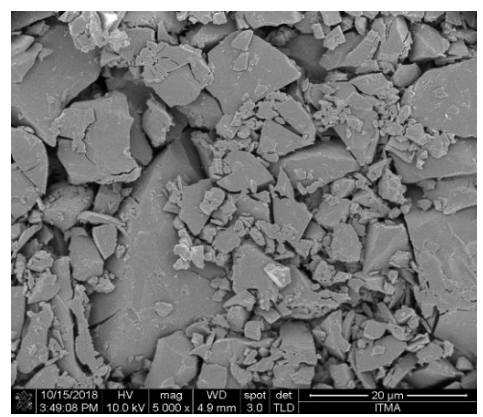

(c)

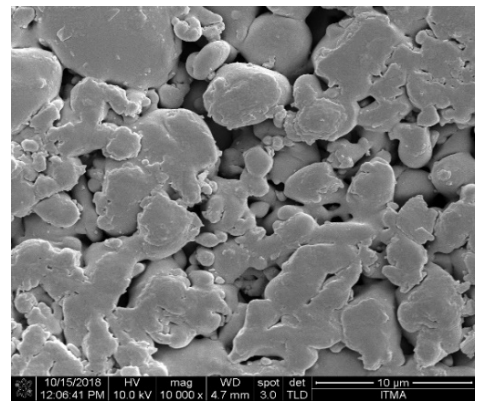

(e)

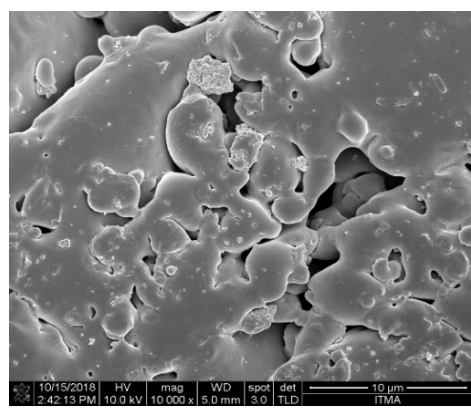

(g)

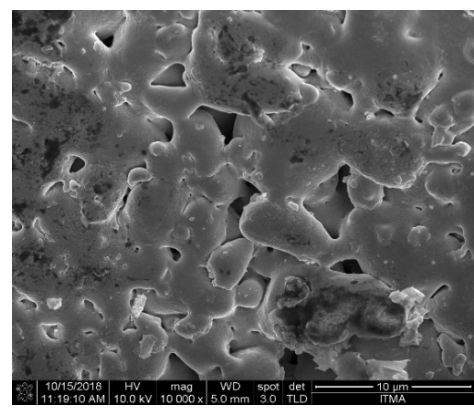

(b)

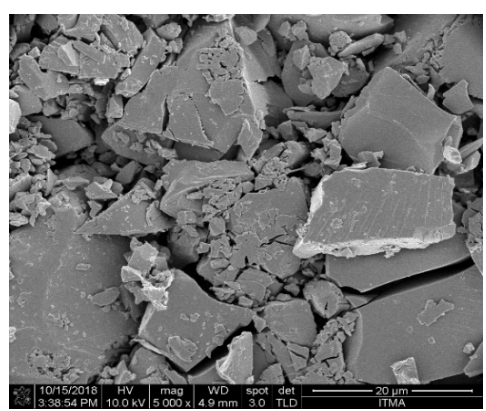

(d)

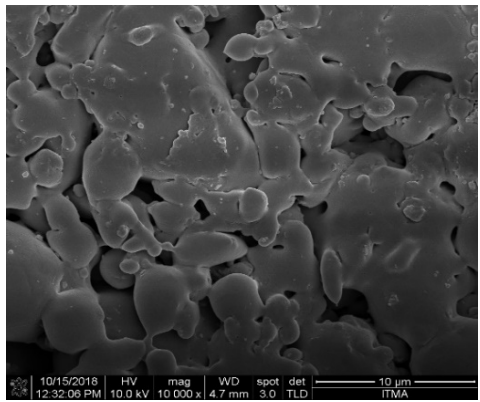

(f)

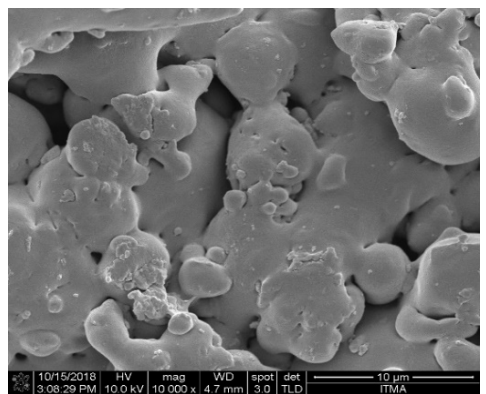

Figure 3. The surface morphology of the zinc silicate glass and glass-ceramics that were heat treated at various sintering temperature: (a) $27^{\circ} \mathrm{C}$, (b) $700{ }^{\circ} \mathrm{C}$, (c) $750{ }^{\circ} \mathrm{C}$, (d) $800^{\circ} \mathrm{C},(\mathbf{e}) 850{ }^{\circ} \mathrm{C},(\mathbf{f}) 900^{\circ} \mathrm{C}$, and $(\mathbf{g}) 950^{\circ} \mathrm{C}$.

\subsection{Fourier Transform Infrared Radiation (FTIR)}

Figure 4 shows the transmittance IR spectra of the zinc silicate glass and glass-ceramics in the region from 400 to $2000 \mathrm{~cm}^{-1}$. The band assignation of the IR spectra is tabulated in Table 2 . 


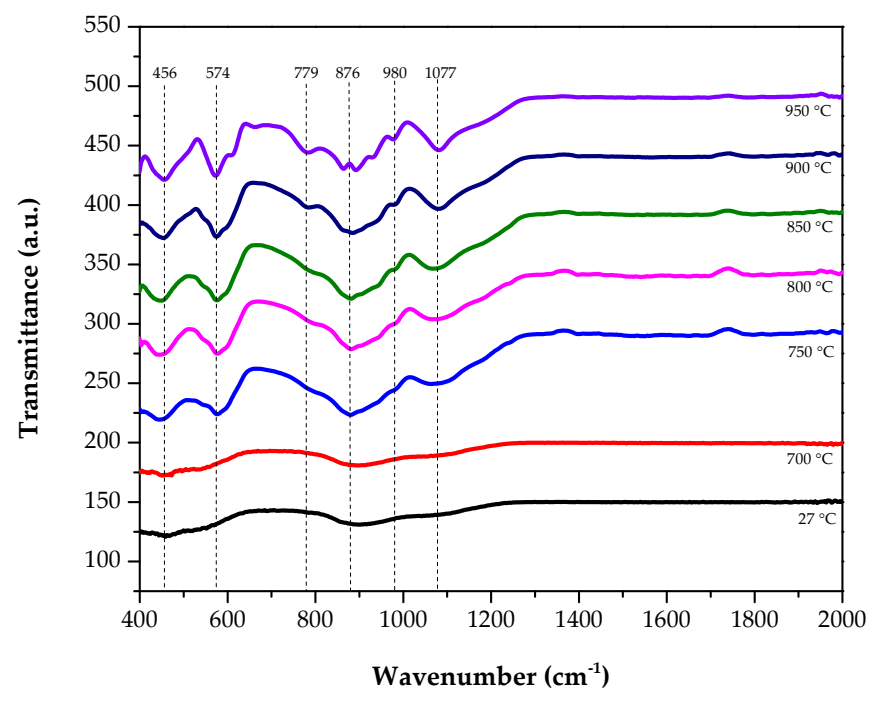

Figure 4. FTIR spectra of the zinc silicate glass and glass-ceramics that were heat treated at various sintering temperatures.

Table 2. FTIR assignment bands for the zinc silicate glass and glass ceramic after sintering [8].

\begin{tabular}{cc}
\hline Wavenumber $\left(\mathbf{c m}^{\mathbf{- 1}}\right)$ & Assignment of Vibrational Mode \\
\hline $450-700$ & $\mathrm{ZnO}_{4}$ symmetric starching vibrations \\
460 & $\mathrm{SiO}_{4}$ asymmetric deformation \\
576 & $\mathrm{Zn}-\mathrm{O}$ symmetric stretching vibration \\
615 & $\mathrm{Zn}-\mathrm{O}$ asymmetric stretching vibration \\
697 & Si-O bond vibration \\
865 & $\mathrm{Si}-\mathrm{O}$ symmetric stretching vibration \\
$900-980$ & Si-O asymmetric stretching vibration \\
\hline
\end{tabular}

\subsection{Photoluminescence (PL)}

Figure 5 shows the emission intensity of the zinc silicate glass and glass-ceramics that were heat treated at $700,750,800,850,900$, and $950{ }^{\circ} \mathrm{C}$, respectively. The samples were excited at a wavelength of $375 \mathrm{~nm}$. Based on Figure 5, it was evident that three broad emission peaks at 529, 570, and $682 \mathrm{~nm}$ appeared.

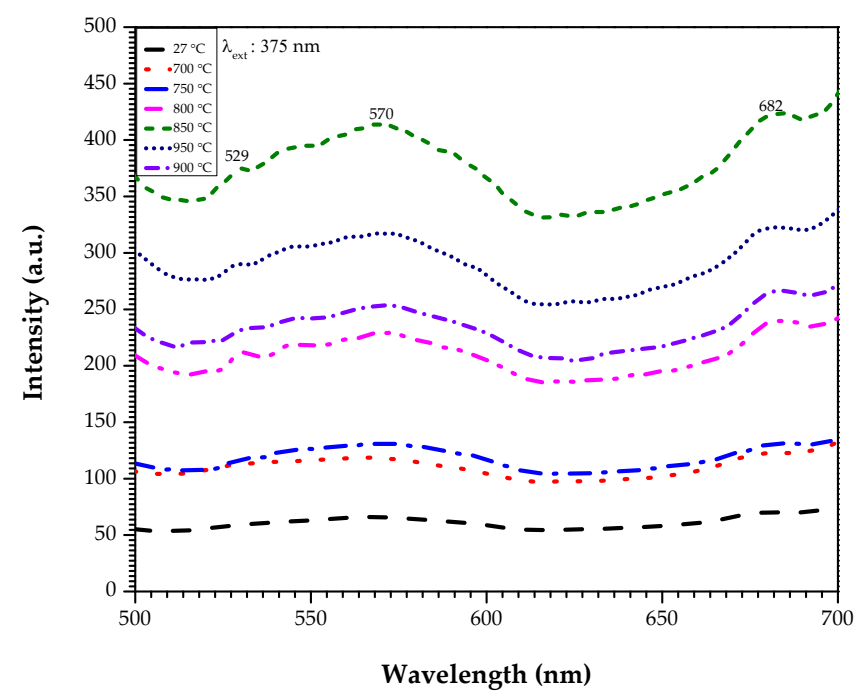

Figure 5. Emission spectra of the zinc silicate glass and glass-ceramics heat treated at various sintering temperatures. 


\section{Discussion}

Density and shrinkage of the zinc silicate glass and glass-ceramics were investigated to observe the physical changes that occurred when the sintering process was carried out. From Figure 1, the density increased from 2.9118 to $3.4138 \mathrm{~g} / \mathrm{cm}^{3}$ as the sintering temperature increased, suggesting a rapid densification. The observation of this densification occurred due to the structure compactness and enhancement of the crystallization phase as the sintering temperature increased. When the structure of the sample became compact, the sample's shrinkage became clear; this can be observed from Figure 1, where the shrinkage increased from $0 \%$ to $7.5 \%$. Apart from that, at a higher temperature, the microstructure and grain size of the sample increased to obtain a denser packing. Consequently, this will lead to the decrement of the total fractional porosity; hence, causing the density to increase. Besides, as the heat was subjected to the sample, it applied pressure on the sample. When pressure was applied, it resulted in a decrease in the volume of the sample. Volume is subjected to be inversely proportional to the density of a material. The lower the volume, the higher the density. In conclusion, the higher the sintering temperature, the higher the density and linear shrinkage of the zinc silicate glass and glass-ceramics.

By looking at the diffraction peaks in Figure 2, it can be observed that, as the sintering temperature increases, the intensity of the XRD peak also increases. The effect of sintering has improved the crystallinity of the zinc silicate [15]. Besides, with the progression of the sintering temperature, the diffraction peaks of the zinc silicate glass-ceramics become sharper and the full width at half maxima (FWHM) is decreased. In the XRD analysis, generally the smaller the crystallite sizes, the broader the peaks; in turn, the larger the crystallite sizes, the sharper the peaks $[11,12,15]$. This is because at a higher sintering temperature, the diffusion of the ions increased, hence making the crystal growth of the sample accelerated, resulting in a larger crystal being produced [12]. This supports the result that was obtained, where it can be observed that the diffraction peak becomes sharper as the sintering temperature increased. The formation of zinc silicate glass and glass-ceramics was further confirmed by using the FESEM and FTIR analysis.

In order to determine the size of the crystal, the type of crystal, and the surface morphology of the zinc silicate glass and glass-ceramics samples, the FESEM analysis was done. From our observations, at the lower temperatures of $27^{\circ} \mathrm{C}$ and $700{ }^{\circ} \mathrm{C}$ there were no grain growth, showing a clear glassy surface that tallies with the XRD result where at $27^{\circ} \mathrm{C}$ and $700^{\circ} \mathrm{C}$ the sample was still in an amorphous phase [16]. Meanwhile, as the sintering temperature increased to $750^{\circ} \mathrm{C}$ and $800{ }^{\circ} \mathrm{C}$, the microstructure of the sample still did not show a regular shape (irregular) and started to aggregate among each other. The formation of crystal growth on the surface of the zinc silicate glass and glass-ceramics proved that at $750{ }^{\circ} \mathrm{C}$ and $800{ }^{\circ} \mathrm{C}$, the crystallization started to occur as in the XRD result. Then, after further sintering, the glass-ceramics appeared to have a greater grain size, indicating an increase in crystallinity. At the highest temperature, the glass-ceramics become densely packed, with strong necking between each other.

Other than that, by carrying out FTIR analysis, the functional groups of the respective zinc silicate glass and glass-ceramics that could appear in the corresponding materials can be obtained. At a lower sintering temperature, there were four broad $\mathrm{SiO}_{4}$ and $\mathrm{ZnO}_{4}$ bands, whose presence was attributed to the bending modes of the O-Si-O and Si-O-Si bonds, $\mathrm{Zn}-\mathrm{O}$ stretching vibrational bond, vibrations of $\mathrm{Zn}-\mathrm{O}$ in the $\mathrm{ZnO}_{4}$ tetrahedral, the decreasing of the Si-O stretching bonds, and the stretching vibrations of the $\mathrm{SiO}_{4}$ and $\mathrm{ZnO}_{4}$ tetrahedron [17]. This four broad $\mathrm{SiO}_{4}$ and $\mathrm{ZnO}_{4}$ bands indicated that there was no formation of zinc silicate glass-ceramics, which agrees with the XRD pattern, where all samples were in an amorphous form at $27^{\circ} \mathrm{C}$ and $700^{\circ} \mathrm{C}$. While, for the IR spectrum of the zinc silicate glass-ceramics, there were eight types of absorption bands located at the $459 \mathrm{~cm}^{-1}$ asymmetric deformation of the $\mathrm{SiO}_{4}$, symmetric stretching of $\mathrm{ZnO}_{4}$ at $576 \mathrm{~cm}^{-1}$, asymmetric stretching of $\mathrm{ZnO}_{4}$ at $615 \mathrm{~cm}^{-1}$, bond vibration of $\mathrm{SiO}_{4}$ at $697 \mathrm{~cm}^{-1}$, symmetric stretching of $\mathrm{SiO}_{4}$ at $865 \mathrm{~cm}^{-1}$, and asymmetric stretching of $\mathrm{SiO}_{4}$ at $905 \mathrm{~cm}^{-1}, 932 \mathrm{~cm}^{-1}$, and $978 \mathrm{~cm}^{-1}$, respectively [18]. From Figure 4, after the sintering temperature reached $750{ }^{\circ} \mathrm{C}$ up to $950{ }^{\circ} \mathrm{C}$, a sharp band at $456 \mathrm{~cm}^{-1}$ was spotted at the IR region, showing the 
asymmetric deformation of the $\mathrm{Si}-\mathrm{O}$ bond in the $\mathrm{SiO}_{4}$ units. Then, a band at $574 \mathrm{~cm}^{-1}$ associated with the $\mathrm{Zn}-\mathrm{O}$ symmetric stretching vibration in the $\mathrm{ZnO}_{4}{ }^{-}$was also spotted. While, for the asymmetric stretching of the $\mathrm{Zn}-\mathrm{O}$ during vibration of the $\mathrm{ZnO}_{4}$ group was located at $615 \mathrm{~cm}^{-1}$. The bands positioned at $779 \mathrm{~cm}^{-1}$ are accredited to the Si-O bond vibration and the bands at $876 \mathrm{~cm}^{-1}$ are subjected to Si-O symmetric stretching vibration [6,19]. Lastly, the band that appeared at $980 \mathrm{~cm}^{-1}$ was transmitted due to the Si-O asymmetric stretching vibration. The band assignation of the IR spectra was tabulated in Table 2. Considering all the IR spectra, it was found that, at first, there were only four broad bands present, proving the formation of the zinc silicate glass. Later, as the sintering temperature increased, there was an additional, sharp band at the IR region, indicating the formation of zinc silicate glass-ceramics, which supports the XRD result.

The photoluminescence spectrometer was cast-off to analyse and prove the luminescence properties of the zinc silicate glass and glass-ceramics by looking at the emission spectra of the sample as in Figure 5, where three broad emission peaks at 529, 570, and $682 \mathrm{~nm}$ appeared. The glass-ceramics reveals green, yellow, and red emission. It was found that the origin of these emission peaks might originate from the intrinsic or native defects in $\mathrm{ZnO}$ [20]. According to Lima and co-researchers, these emissions can be attributed to the following transitions: $\mathrm{Zn}_{\mathrm{i}}^{+} \rightarrow \mathrm{Vzn}^{-}$at $529 \mathrm{~nm}, \mathrm{Vzn}^{-} \rightarrow \mathrm{Vzn}^{-}$ at $570 \mathrm{~nm}$, and $\mathrm{CB} \rightarrow \mathrm{V}_{\mathrm{o}}^{+} / \mathrm{V}_{\mathrm{o}}^{+} \rightarrow \mathrm{VB}$ at $682 \mathrm{~nm}$ [21]. The green emission happened due to the electron-hole recombination, in which the electron was trapped at the singly ionized oxygen vacancy $\left(V_{o}\right)$ centre; then, it recombined with the hole in the valance band (VB) [22]. The recombination process between the electron and hole releases the green emission. Moreover, based on study by Ramanachalam and co-researchers, it has been concluded that the centre/origin of the green luminescence in $\mathrm{ZnO}$ can be either the zinc interstitial $\left(\mathrm{Zn}_{\mathrm{i}}\right)$ and/or $\mathrm{V}_{\mathrm{o}}$ [20]. Apart from that, it has been discussed that the $\mathrm{Zn}^{2+}$ ions are the ones that caused the green emission to occur and appear in zinc silicate glass and glass-ceramics [22-24]. The green emission of the zinc silicate glass and glass-ceramics was attributed to the radiative decay of the electronic defect that happened in the forbidden band. Meanwhile, the broad yellow emission at $570 \mathrm{~nm}$ was probably due to the intrinsic or excess of oxygen [25]. Previously, a few researchers had proposed that the centre origin of yellow luminescence could be the zinc vacancy (Vzn) oxygen interstitial $\left(\mathrm{O}_{\mathrm{i}}\right)$ and other defects [20,26-28]. According to Lui and co-researchers, the yellow luminescence of high purity $\mathrm{ZnO}$ may happen due to the intrinsic and excess of oxygen. Moreover, Ramanchalam and co-researchers had discussed that the $\mathrm{O}_{\mathrm{i}}$ may be the yellow luminescence centre of the pure $\mathrm{ZnO}$ and $\mathrm{ZnO}$ varistor [20]. In the meantime, the red emission at $682 \mathrm{~nm}$ may be emitted due to the $\mathrm{O}_{\mathrm{i}}$ or $\mathrm{V}_{\mathrm{o}}$. Based on the study by Alvi and co-researchers, it has been found that the origin of the $\mathrm{ZnO}$-nanotubes red emission in the range of $620 \mathrm{~nm}$ to $690 \mathrm{~nm}$ was attributed to the $\mathrm{O}_{\mathrm{i}}$; meanwhile, red emission in the range of $690 \mathrm{~nm}$ to $750 \mathrm{~nm}$ was due to $V_{o}$ [29]. Therefore, since the emission occurred at $682 \mathrm{~nm}$, there might be a chance that the emission occurred due to $V_{0}$. Other than that, from Figure 5 , it was also observed that the emission peak intensity increased as the sintering temperature increased. This increment occurred as a result from the improvement of the crystallinity inside the zinc silicate glass and glass-ceramics sample [30]. When heat is applied to the zinc silicate sample, this will cause changes in the donor and the acceptor levels of the electron, in which it is interrelated with the number of electronic defects. The presence of the zinc interstitial defect lead to the increase in the emission intensity. Besides, according to Fujihara and co-researchers, the photoluminescence intensity of the materials depends on the amount of $\mathrm{ZnO}$ provided due to the oxygen defect, and is dependent on the heat given to the sample [22]. Hence, as was discussed above, it can be concluded that the sintering temperature also affects the intensity of the zinc silicate glass and glass-ceramics emission.

\section{Conclusions}

In conclusion, the effect of sintering on the structural and optical properties of zinc silicate glass and glass-ceramics derived from WRHA by the melt and quenching technique is demonstrated. The density is increased as the sintering temperature increased and linearly increased with the sample shrinkage. Meanwhile, from the XRD result, it was obtained that the crystallinity of the zinc silicate glass-ceramics 
increased as the sintering temperature increased. Besides, the $\beta-\mathrm{Zn}_{2} \mathrm{SiO}_{4}$ phase of the zinc silicate was formed at $750{ }^{\circ} \mathrm{C}$ until $850{ }^{\circ} \mathrm{C}$. Then it thermodynamically changed into the $\alpha-\mathrm{Zn}_{2} \mathrm{SiO}_{4}$ phase of zinc silicate as the temperature reached $900{ }^{\circ} \mathrm{C}$ and $950{ }^{\circ} \mathrm{C}$. The surface morphology has revealed the glass and glass-ceramics formations; thus, the FTIR spectra showed the formation of the zinc silicate glass and glass-ceramics, supporting the finding from the XRD analysis. Lastly, the photoluminescence spectroscopy revealed a green, yellow, and red emission indicating the luminescence zinc silicate glass and glass-ceramics. The luminescence properties of the zinc silicate portrayed in this study suggest that this zinc silicate is suitable for optical applications.

Author Contributions: S.A.A.W., K.A.M. and M.H.M.Z. participated in the planning and design of the study, as well as prepared the manuscript; M.M.A.K. and S.H.A.A. joined as the project observer and conceptualization; R.A.T. was the project monitor for the density measurement; A.Z.K.A., R.E.M.K., M.Z.A.K. and N.E. helped conduct the experiment, collected data, and analysed the data. All authors have read and agreed to the published version of the manuscript.

Funding: The author gracefully acknowledged the financial support from Ministry of Science, Technology and Innovation, Malaysia and Universiti Putra Malaysia (UPM), each under the Fundamental Research Grant Scheme (FRGS-5540163), Inisiatif Putra Berimpak (IPM-9531300) and Inisiatif Putra Siswazah (IPS-9627500).

Conflicts of Interest: The authors declare that there is no conflict of interests regarding the publication of this article.

\section{References}

1. Pode, R. Potential applications of rice husk ash waste from rice husk biomass power plant. Renew. Sustain. Energy Rev. 2016, 53, 1468-1485. [CrossRef]

2. Bondioli, F.; Barbieri, L.; Ferrari, A.M.; Manfredini, T. Characterization of rice husk ash and its recycling as quartz substitute for the production of ceramic glazes. J. Am. Ceram. Soc. 2010, 93, 121-126. [CrossRef]

3. Pode, R.; Diouf, B.; Pode, G. Sustainable rural electrification using rice husk biomass energy: A case study of Cambodia. Renew. Sustain. Energy Rev. 2015, 44, 530-542. [CrossRef]

4. Lee, C.S.; Matori, K.A.; Ab Aziz, S.H.; Kamari, H.M.; Ismail, I.; Zaid, M.H.M. Fabrication and characterization of glass and glass-ceramics from rice husk ash as a potent material for opto-electronic applications. J. Mater. Sci. Mater. Electron. 2017, 28, 17611-17621. [CrossRef]

5. Khaidir, R.E.M.; Fen, Y.W.; Zaid, M.H.M.; Matori, K.A.; Omar, N.A.S.; Anuar, M.F.; Wahab, S.A.A.; Azman, A.Z.K. Exploring $\mathrm{Eu}^{3+}$-doped $\mathrm{ZnO}-\mathrm{SiO}_{2}$ glass derived by recycling renewable source of waste rice husk for white-LEDs application. Results Phys. 2019, 15, 102596. [CrossRef]

6. Wahab, S.A.A.; Matori, K.A.; Aziz, S.H.A.; Zaid, M.H.M.; Kechik, M.M.A.; Azman, A.Z.K.; Khiri, M.Z.A.; Effendy, N. Synthesis of cobalt oxide $\mathrm{Co}_{3} \mathrm{O}_{4}$ doped zinc silicate based glass-ceramics derived for LED applications. Optik 2019, 179, 919-926. [CrossRef]

7. Feldmann, C.; Jüstel, T.; Ronda, C.R.; Schmidt, P.J. Inorganic luminescent materials: 100 years of research and application. Adv. Funct. Mater. 2003, 13, 511-516. [CrossRef]

8. Zaid, M.H.M.; Matori, K.A.; Aziz, S.H.A.; Kamari, H.M.; Wahab, Z.A.; Fen, Y.W.; Alibe, I.M. Synthesis and characterization of low cost willemite based glass-ceramic for opto-electronic applications. J. Mater. Sci. Mater. Electron. 2016, 27, 11158-11167. [CrossRef]

9. Sarrigani, G.V.; Matori, K.A.; Lim, W.F.; Kharazmi, A.; Quah, H.J.; Bahari, H.R.; Hashim, M. Structural and optical properties of erbium-doped willemite-based glass-ceramics. Appl. Opt. 2015, 54, 9925-9929. [CrossRef]

10. Effendy, N.; Wahab, Z.A.; Abdul Aziz, S.H.; Matori, K.A.; Zaid, M.H.M.; Rashid, S.S.A. Characterization and optical properties of erbium oxide doped ZnO-SLS glass for potential optical and optoelectronic materials. Mater. Express 2017, 7, 59-65. [CrossRef]

11. Effendy, N.; Wahab, Z.A.; Kamari, H.M.; Matori, K.A.; Ab Aziz, S.H.; Zaid, M.H.M. Structural and optical properties of $\mathrm{Er}^{3+}$-doped willemite glass-ceramics from waste materials. Optik 2016, 127, 11698-11705. [CrossRef]

12. Zaid, M.H.M.; Matori, K.A.; Aziz, S.H.A.; Kamari, H.M.; Yunus, W.M.M.; Samsudin, N.F. Fabrication and crystallization of ZnO-SLS glass derived willemite glass-ceramics as a potential material for optics applications. J. Spec. 2016, 2016, 8084301. 
13. Takesue, M.; Hayashi, H.; Smith, R.L., Jr. Thermal and chemical methods for producing zinc silicate (willemite): A review. Prog. Cryst. Growth Charact. Mater. 2009, 55, 98-124. [CrossRef]

14. Tarafder, A.; Molla, A.R.; Dey, C.; Karmakar, B. Thermal, Structural, and Enhanced Photoluminescence Properties of $\mathrm{Eu}^{3+}$-doped Transparent Willemite Glass-Ceramic Nanocomposites. J. Am. Ceram. Soc. 2013, 96, 2424-2431. [CrossRef]

15. Omar, N.A.S.; Fen, Y.W.; Matori, K.A.; Aziz, S.H.A.; Alassan, Z.N.; Samsudin, N.F. Development and characterization studies of $\mathrm{Eu}^{3+}$-doped $\mathrm{Zn}_{2} \mathrm{SiO}_{4}$ phosphors with waste silicate sources. Procedia Chem. 2016, 19, 21-29. [CrossRef]

16. Khaidir, R.E.M.; Fen, Y.W.; Zaid, M.H.M.; Matori, K.A.; Omar, N.A.S.; Anuar, M.F.; Wahab, S.A.A.; Azman, A.Z.K. Optical band gap and photoluminescence studies of $\mathrm{Eu}^{3+}$-doped zinc silicate derived from waste rice husks. Optik 2019, 182, 486-495. [CrossRef]

17. Sarrigani, G.V.; Quah, H.J.; Lim, W.F.; Matori, K.A.; Mohd Razali, N.S.; Kharazmi, A.; Hashim, M.; Bahari, H.R. Characterization of waste material derived willemite-based glass-ceramics doped with erbium. Adv. Mater. Sci. Eng. 2015, 2015, 953659. [CrossRef]

18. Syamimi, N.F.; Matori, K.A.; Lim, W.F.; Aziz, S.H.A.; Zaid, M.H.M. Effect of Sintering Temperature on Structural and Morphological Properties of Europium (III) Oxide Doped Willemite. J. Spec. 2014, 2014, 328931. [CrossRef]

19. Azman, A.Z.K.; Matori, K.A.; Aziz, S.H.A.; Zaid, M.H.M.; Wahab, S.A.A.; Khaidir, R.E.M. Comprehensive study on structural and optical properties of $\mathrm{Tm}_{2} \mathrm{O}_{3}$ doped zinc silicate based glass-ceramics. J. Mater. Sci. Mater. Electron. 2018, 29, 19861-19866. [CrossRef]

20. Ramanachalam, M.S.; Rohatgi, A.; Carter, W.B.; Schaffer, J.P.; Gupta, T.K. Photoluminescence study of ZnO varistor stability. J. Electron. Mater. 1995, 24, 413-419. [CrossRef]

21. Lima, S.A.M.; Sigoli, F.A.; Jafelicci, M., Jr.; Davolos, M.R. Luminescent properties and lattice defects correlation on zinc oxide. Int. J. Inorg. Mater. 2001, 3, 749-754. [CrossRef]

22. Fujihara, S.; Naito, H.; Kimura, T. Visible photoluminescence of ZnO nanoparticles dispersed in highly transparent $\mathrm{MgF}_{2}$ thin-films via sol-gel process. Thin Solid Films 2001, 389, 227-232. [CrossRef]

23. Janotti, A.; Van de Walle, C.G. Fundamentals of zinc oxide as a semiconductor. Rep. Prog. Phys. 2009, 72, 126501. [CrossRef]

24. Fu, Z.; Yang, B.; Li, L.; Dong, W.; Jia, C.; Wu, W. An intense ultraviolet photoluminescence in sol-gel $\mathrm{ZnO}-\mathrm{SiO}_{2}$ nanocomposites. J. Phys. Condes. Matter 2003, 15, 2867. [CrossRef]

25. Liu, M.; Kitai, A.H.; Mascher, P. Point defects and luminescence centres in zinc oxide and zinc oxide doped with manganese. J. Lumin. 1992, 54, 35-42. [CrossRef]

26. Hirshwald, W.; Bonasewicz, P.; Ernst, L.; Grade, M.; Hoffman, D.; Krebs, S.; Littbarski, R.; Neumann, G.; Grunze, M.; Kolb, D.; et al. Current Topics in Materials Science; Kaldis, E., Ed.; North Holland: Amsterdam, the Netherlands, 1981; Volume 7, p. 241.

27. Riehl, N. Intrinsic defects and luminescence in II-VI-compounds. J. Lumin. 1981, 24, 335-342. [CrossRef]

28. Zelikin, Y.M.; Zhukovskii, A.M. Yellow Luminescence of Zinc Oxide. Opt. Spektrosk. 1961, 11, $212-215$.

29. Alvi, N.H.; Ul Hasan, K.; Nur, O.; Willander, M. The origin of the red emission in n-ZnO nanotubes/p-GaN white light emitting diodes. Nanoscale Res. Lett. 2011, 6, 130. [CrossRef]

30. Li, J.; Kuwabara, M. Preparation and luminescent properties of Eu-doped $\mathrm{BaTiO}_{3}$ thin films by sol-gel process. Sci. Technol. Adv. Mater. 2003, 4, 143-148. [CrossRef]

(C) 2020 by the authors. Licensee MDPI, Basel, Switzerland. This article is an open access article distributed under the terms and conditions of the Creative Commons Attribution (CC BY) license (http://creativecommons.org/licenses/by/4.0/). 